Case Reports in
Gastroenterology
Case Rep Gastroenterol 2020;14:652-657

DOI: 10.1159/000509951

Published online: December 3, 2020

(c) 2020 The Author(s)

Published by S. Karger AG, Basel www.karger.com/crg

This article is licensed under the Creative Commons Attribution-NonCommercial 4.0 International License (CC BY-NC) (http://www.karger.com/Services/OpenAccessLicense). Usage and distribution for commercial purposes requires written permission.

\title{
A Bitter Pill to Swallow: Pseudoachalasia Secondary to Oesophageal Deviation Resulting from Mediastinal Shift and Left Atrial Enlargement after Left Lower Lobectomy
}

\author{
Magali M.V.P. Surmont ${ }^{a} \quad$ Maridi Aerts ${ }^{a} \quad$ Rastislav Kunda ${ }^{a-c}$ \\ Sébastien Kindt ${ }^{\mathrm{a}}$ \\ aDepartment of Gastroenterology-Hepatology, Universitair Ziekenhuis Brussel (UZ \\ Brussel)/Vrije Universiteit Brussel (VUB), Brussels, Belgium; 'b Department of Surgery, \\ Universitair Ziekenhuis Brussel (UZ Brussel)/Vrije Universiteit Brussel (VUB), \\ Brussels, Belgium; 'Department of Advanced Interventional Endoscopy, Universitair \\ Ziekenhuis Brussel (UZ Brussel)/Vrije Universiteit Brussel (VUB), Brussels, Belgium
}

\section{Keywords}

Case report · Pseudoachalasia $\cdot$ Secondary achalasia $\cdot$ Oesophagus · Motility · Oesophageal manometry

\section{Abstract}

Pseudoachalasia, also known as secondary achalasia, is a rare clinical condition mimicking idiopathic achalasia but unrelated to primary loss of nitrergic innervation. It has mostly been attributed to malignancy infiltrating the oesophageal wall, but several other benign underlying pathologies have been reported. Because of similar manometric appearance, high-resolution manometry (HRM) of the oesophagus alone cannot distinguish between idiopathic achalasia and pseudoachalasia. Misdiagnosis can result in ineffective treatment by dilatation or even more invasive therapy. This is the first case-report of pseudoachalasia secondary to oesophageal deviation resulting from mediastinal shift and left atrial enlargement following prior left

$\begin{array}{ll} & \text { Magali M.V.P. Surmont } \\ \text { Department of Gastroenterology-Hepatology } & \text { Universitair Ziekenhuis Brussel (UZ Brussel)/Vrije Universiteit Brussel (VUB) } \\ \text { Laarbeeklaan 101, BE-1090 Brussels (Belgium) } \\ \text { Magali.Surmont@uzbrussel.be }\end{array}$




\section{Case Reports in Gastroenterology}

Case Rep Gastroenterol 2020;14:652-657 DOI: 10.1159/000509951

c) 2020 The Author(s). Published by S. Karger AG, Basel www.karger.com/crg

Surmont et al.: Pseudoachalasia Secondary to Oesophageal Deviation Resulting from Mediastinal Shift and Left Atrial Enlargement after Left Lower Lobectomy

lower lobectomy. HRM, the gold standard for the diagnosis of achalasia, confirmed the incomplete relaxation of the lower oesophageal sphincter (LES) in absence of normal oesophageal peristalsis. However, additional workup with CAT scan and cardiac ultrasound identified an anatomical shift by the extrinsic mass effect resulting from the atrial enlargement, but without contrast retention at the LES.

(c) 2020 The Author(s)

Published by S. Karger AG, Basel

\section{Introduction}

Idiopathic achalasia is a primary motility disorder in which incomplete relaxation of the lower oesophageal sphincter (LES) in absence of normal peristalsis results in stasis of ingested food. Clinical symptoms are dysphagia, regurgitation, chest pain, and weight loss. Barium oesophagram typically reveals a bird's beak sign, oesophageal dilatation, or a corkscrew appearance. High-resolution manometry (HRM) of the oesophagus is considered the gold standard for diagnosis of achalasia [1]. Based on the Chicago classification, achalasia is identified as an impaired relaxation of the LES in the absence of normal peristalsis on HRM $[1,2]$.

Pseudoachalasia, also known as secondary achalasia, is a rare clinical condition mimicking idiopathic achalasia. It accounts for 2 to $5 \%$ of patients with an achalasia-like syndrome $[3,4]$. Whereas primary achalasia is generated by primary degeneration of the oesophageal ganglion cells, and especially the inhibiting nitrergic neurons, pseudoachalasia has most commonly been described in relation to underlying malignancy $[1,3]$.

\section{Case Report/Case Presentation}

An 80-year-old man presented in May 2019 to the outpatient clinic for further investigation of long-standing daily dysphagia for solid food with associated regurgitation and occasional retrosternal pain. He reported a weight loss of less than $5 \mathrm{~kg}$ over the last 6 months, contributing to an Eckardt score of 6 . He was known with ischemic cardiomyopathy with enlargement of the left atrium. A left lower pulmonary lobectomy was performed in 1955 because of non-tuberculosis related abscess. Before his referral for further investigation, repeated upper gastrointestinal endoscopy since May 2017 provided no explanation for the dysphagia. Oesophageal biopsies excluded eosinophilic oesophagitis. Based on the presence of stasis of contrast in the middle third of the oesophagus, associated with tertiary contractions during radiologic evaluation but without manometric evidence of achalasia, pneumatic dilatation up to $20 \mathrm{~mm}$ was performed twice. Because of the lack of clinical response, he was referred to our centre for further diagnostics. Upper gastrointestinal endoscopy identified candidosis, for which fluconazole was initiated, without improvement of symptoms. Oesophageal HRM (Manoscan ${ }^{\mathrm{TM}}$ Eso High Resolution Manometry System, Medtronic ${ }^{\circledR}$, Minneapolis, MN, USA) indicated a $20.5 \mathrm{~mm} \mathrm{Hg}$ integrated relaxation pressure (normal $<15 \mathrm{~mm} \mathrm{Hg}$ ) and 30\% failed peristalsis with panoesophageal pressurization compatible with type II achalasia (1) (shown in Fig. 1). Barium oesophagram showed a dilated oesophagus but no typical bird's peak sign. Contrast series demonstrated a lateral deviation of the distal oesophagus attributable to left atrium enlargement in the presence of a leftward mediastinal shift (shown in Fig. 2). This was further confirmed by CAT scan (shown in Fig. 3). Contrast retention was observed in the proximal oesophagus, but with normal oesophageal emptying at the LES. No lung cancer

\section{Karger's'}




\section{Case Reports in Gastroenterology}

Case Rep Gastroenterol 2020;14:652-657 DOI: 10.1159/000509951

c) 2020 The Author(s). Published by S. Karger AG, Basel www.karger.com/crg

Surmont et al.: Pseudoachalasia Secondary to Oesophageal Deviation Resulting from Mediastinal Shift and Left Atrial Enlargement after Left Lower Lobectomy

was identified. Cardiac ultrasound confirmed the enlargement of the left atrium with reduced contractility in the inferoseptal part of the left ventricular wall. Because of the advanced age and associated comorbidities, a conservative treatment with introduction of small meals and interruption of opioids was advocated. At follow-up, symptoms of dysphagia were sufficiently controlled without need for additional treatment; Eckardt score lowered to 3 with occasional dysphagia, regurgitation, and retrosternal pain but stable weight.

\section{Discussion}

This is, to our knowledge, the first case of pseudoachalasia secondary to oesophageal deviation resulting from mediastinal shift and left atrial enlargement after prior left lower lobectomy. The lateral shift of the distal oesophagus resulted in manometric and radiological findings similar to primary achalasia. Workup with CAT scan and cardiac ultrasound identified an anatomical shift and extrinsic mass effect of the atrial enlargement as the underlying cause.

In up to $70 \%$ of these cases, an infiltrating adenocarcinoma of the gastro-oesophageal junction arising in the cardia or on a Barrett's oesophagus is implicated [3]. Other less frequent malignant causes with a similar effect are mediastinal and peritoneal metastases and other neoplasms including those of lung, breast, pancreas, and kidney [3, 4]. Laparoscopic adjusting gastric banding is the most common non-malignant cause (6\%) of pseudoachalasia [3]. Diverse rare cases of pseudoachalasia secondary to sarcoidosis, amyloidosis, infectious diseases (e.g., Chagas' disease) as well as cases following vagotomy, Nissen's fundoplication, descending aorta aneurysm, histiocytosis, mediastinal fibrosis, and post-sleeve gastrectomy have been reported [3].

Different hypotheses about the pathophysiology of pseudoachalasia exist. Dysphagia and an achalasia-pattern can be caused by a direct or extrinsic mass-effect of a tumour. Alternatively, malignant invasion of the myenteric plexus can result in dysmotility. Pseudoachalasia also occurs as a paraneoplastic syndrome, mostly associated to small cell lung cancers, with autoimmune damage to the myenteric plexus [3].

Similar to what happened to the patient in this case, a systematic review in 2020 indicated that $24 \%$ of all pseudoachalasia cases were initially wrongly diagnosed and treated as achalasia with Heller myotomy, pneumatic dilatation, or injection of botulinum toxin [3]. Only 3\% of these cases were non-malignant pseudoachalasia.

The most common cause of pseudoachalasia is malignancy. Recognised risk factors for malignant pseudoachalasia are age above 55 at the time of diagnosis, a short duration of symptoms, weight loss of more than $10 \mathrm{~kg}$ on presentation, and difficulty passing the lower gastrooesophageal junction with the scope [5]. Additional investigations to rule out malignancy are warranted when achalasia patients have two or more of these risk factors $[1,4,5]$. Specific risk factors for non-malignant pseudoachalasia have not been studied but awareness about pseudoachalasia is essential, since misdiagnosis exposes patients to futile treatments and potential complications.

\section{Acknowledgement}

I wish to show my gratitude to co-authors Maridi Aerts, Rastislav Kunda, and Sébastien Kindt.

\section{Karger'=}




\section{Case Reports in Gastroenterology}

\begin{tabular}{l|l}
\hline Case Rep Gastroenterol 2020;14:652-657 \\
\hline DOI: 10.1159/000509951 & $\begin{array}{l}\text { @ 2020 The Author(s). Published by S. Karger AG, Basel } \\
\text { www.karger.com/crg }\end{array}$ \\
\hline
\end{tabular}

Surmont et al.: Pseudoachalasia Secondary to Oesophageal Deviation Resulting from Mediastinal Shift and Left Atrial Enlargement after Left Lower Lobectomy

\section{Statement of Ethics}

The subject gave his informed consent to publish this case.

\section{Conflict of Interest Statement}

Magali Surmont: grant to attend meeting from Gilead. Maridi Aerts: no conflicts of interest to declare. Rastislav Kunda: consultant for Olympus Medical, BCM Korea, TaeWoong Korea, Apollo Endosurgery; consultant and Medical Advisory Board for Boston Scientific. Sébastien Kindt: grant to attend meeting from Menarini, Belgium.

\section{Funding Sources}

There was no funding.

\section{Author Contributions}

Magali Surmont took the lead in writing the manuscript. Dr. Maridi Aerts, Prof. Dr. Rastislav Kunda, and Prof. Dr. Sébastien Kindt checked the paper and provided critical feedback to the final manuscript.

\section{References}

1 Oude Nijhuis RA, Zaninotto G, Roman S, Boeckxstaens GE, Fockens P, Langendam MW, et al. European guidelines on achalasia: United European Gastroenterology and European Society of Neurogastroenterology and Motility recommendations. United European Gastroenterol J. 2020 Feb;8(1):13-33.

2 Kahrilas PJ, Bredenoord AJ, Fox M, Gyawali CP, Roman S, Smout AJ, et al.; International High Resolution Manometry Working Group. The Chicago Classification of esophageal motility disorders, v3.0.

Neurogastroenterol Motil. 2015 Feb;27(2):160-74.

3 Schizas D, Theochari NA, Katsaros I, Mylonas KS, Triantafyllou T, Michalinos A, et al. Pseudoachalasia: a systematic review of the literature. Esophagus. 2020 Jul;17(3):216-22.

4 Patel DA, Lappas BM, Vaezi MF. An overview of achalasia and its subtypes. Gastroenterol Hepatol (N Y). 2017 Jul;13(7):411-21.

5 Ponds FA, van Raath MI, Mohamed SM, Smout AJ, Bredenoord AJ. Diagnostic features of malignancyassociated pseudoachalasia. Aliment Pharmacol Ther. 2017 Jun;45(11):1449-58. 
Case Reports in Gastroenterology
Case Rep Gastroenterol 2020;14:652-657

DOI: $10.1159 / 000509951$

(c) 2020 The Author(s). Published by S. Karger AG, Basel www.karger.com/crg

Surmont et al: Pseudoachalasia Secondary to Oesophageal Deviation Resulting from Mediastinal Shift and Left Atrial Enlargement after Left Lower Lobectomy

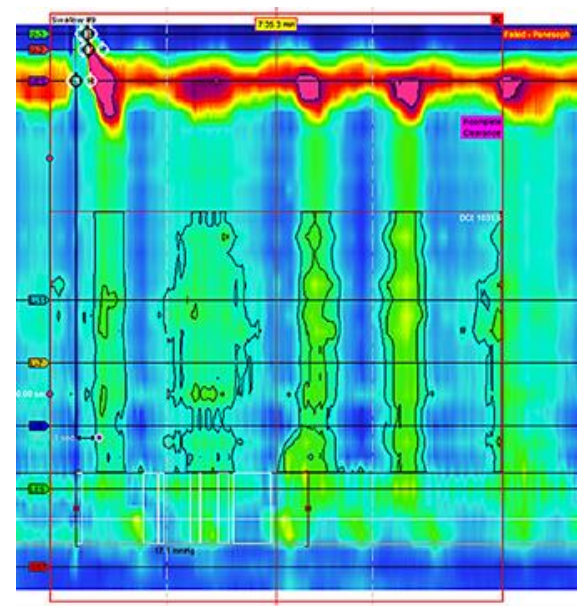

Fig. 1. Oesophageal manometry: type II achalasia.
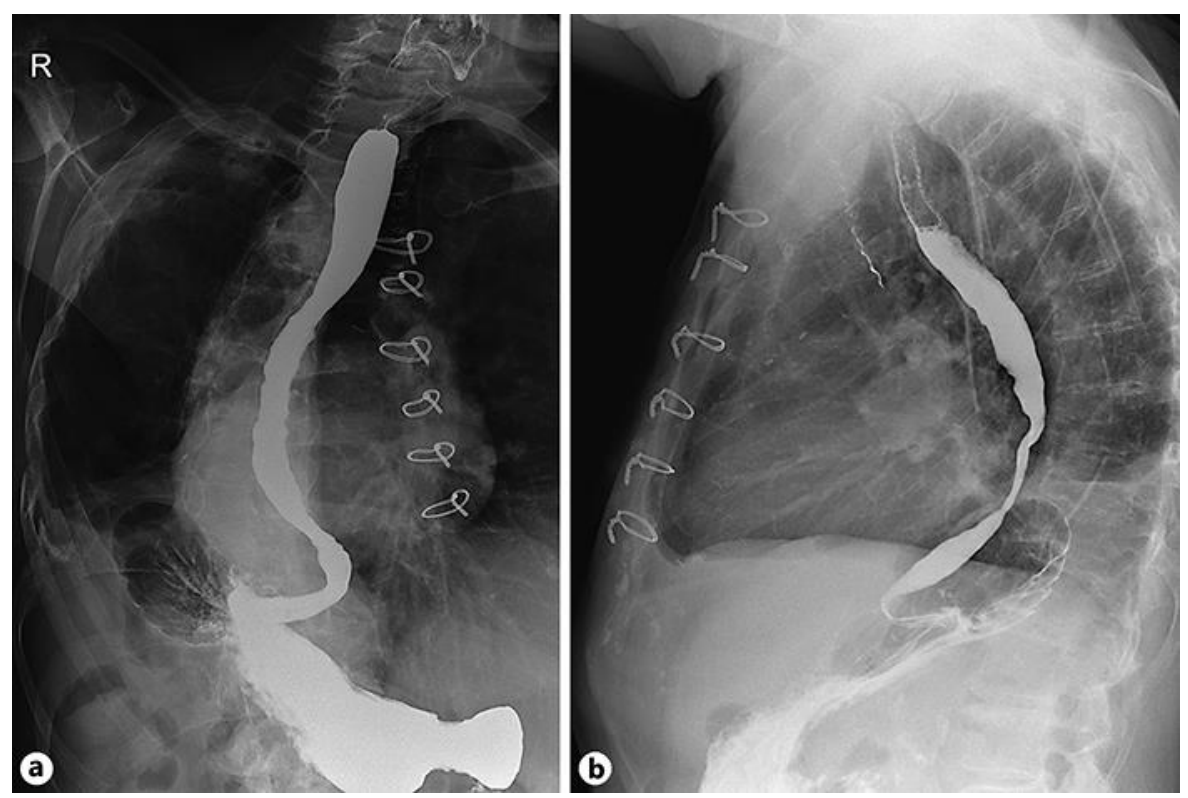

Fig. 2. a Barium oesophagram en face with deviation of the distal oesophagus. b Barium oesophagram in left posterior oblique position with dilatation of oesophagus. 
Case Reports in Gastroenterology

\begin{tabular}{l|l}
\hline Case Rep Gastroenterol 2020;14:652-657 \\
\hline DOI: 10.1159/000509951 & $\begin{array}{l}\text { @ 2020 The Author(s). Published by S. Karger AG, Basel } \\
\text { www.karger.com/crg }\end{array}$ \\
\hline
\end{tabular}

Surmont et al:: Pseudoachalasia Secondary to Oesophageal Deviation Resulting from Mediastinal Shift and Left Atrial Enlargement after Left Lower Lobectomy

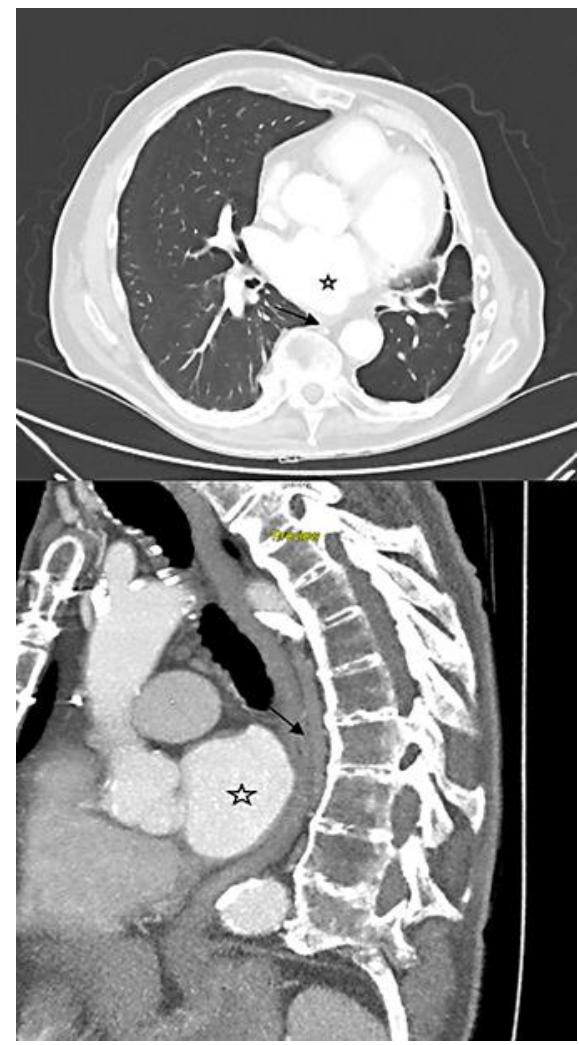

Fig. 3. CAT scan: left atrial enlargement and leftward mediastinal shift resulting in pressure on the oesophagus. 